\title{
An Evaluation of English Language Textbook: Interlanguage English for Senior High School Students
}

\author{
Muhammad Affan Ramadhana ${ }^{* 1}$, Opik Dwi Indah ${ }^{2}$, Suhardi ${ }^{3}$ \\ 1,2,3 Universitas Cokroaminoto Palopo \\ *affanramadhana@uncp.ac.id
}

\begin{abstract}
English Language Teaching (ELT) textbooks serve as the basis for many language inputs that learners receive and language practices that occur in the classroom. They may provide the basis for ideas and instructional activities as well as giving teachers rationales for what they do. The objective of this analysis is to know about how much a textbook meets the requirements of a good EFL textbook. The evaluation checklist used in this paper is the modification of Cunningsworth's (1995) checklist developed by Al-sowat (2012). There are nine issues of textbook evaluating in this checklist: (1) layout and physical appearance; (2) content; (3) objectives; (4) language type; (5) skills; (6) activities and tasks; (7) structure and vocabulary; (8) culture values; and (9) teacher's needs.
\end{abstract}

Keywords: textbook analysis, interlanguage, evaluation, English, senior high school

\section{Introduction}

English Language Teaching (ELT) textbooks play a very important role in language classrooms. In some situations, they serve as the basis for many language inputs that learners receive and language practices that occur in the classroom. They may provide the basis for the content of the lessons, the balance of skills being taught, and the kinds of language practice the students take part in. Materials should make students learn. They should also be the resource books for ideas and instructional activities as well as giving teachers rationales for what they do. In addition, materials also should be suitable with students' needs. Therefore, the textbooks being used in Indonesia for English as Foreign Language (EFL) in particular must go along with the EFL learners' needs. In EFL situation, students rarely have chances to use English outside the classroom, consequently English textbook seems to be the only source by which students receive input and the main material for both teachers and students to rely on ass well (Park, 2004:2).

Indeed, teachers and students also need a source to be used as guidance in the classroom. Therefore, textbooks become the main sources on daily basis. However, textbooks must be used appropriately in order to achieve the objectives. Here are some of the roles of textbook in teaching. Firstly, a textbook is an aid of teaching and learning. Hutchinson and Torres (in Awasthi,2006:1) explain that textbook is an almost universal element of teaching and guidance for a teacher, a memory aid for pupils, and a permanent record for measuring what has been learnt. Secondly, a textbook can also become the supplement for teachers' instruction in classroom. Thirdly, a textbook for inexperienced teachers can provide ideas on kinds of materials and techniques. In addition, a textbook can be the guidance for teachers in 
giving the systematic materials for the students. It is generally accepted that the role of the textbook is to be at the service of teachers and learners but not to be their master.

Cunningsworth (1995) informs that there are three types of materials evaluation: Pre-use evaluation, in-use evaluation, and post-use evaluation. Pre-use evaluation might be implemented when there is no actual experience of using the book for teachers to draw on. Inuse evaluation refers to textbook evaluation whilst the materials are in use. Post-use evaluation provides retrospective assessment of a textbook's performance and can be useful for identifying strengths and weaknesses, which emerge over a period of continuous use.

Related to the problems above, the objective of this analysis is to know about how much a textbook meets requirements of a good EFL textbook. The result of this research is expected to be useful information to help the teacher to evaluate whether the selected materials have already matched with the young learners' needs or not, so that they can have some decision to improve the students' English competence for better future.

\section{Method}

The textbook analysed in this paper is EFL textbook for senior high school students in science and social study program, entitled Interlanguage: English for Senior High School Students XII. The book was issued by Pusat Perbukuan Departemen Pendidikan Nasional in 2008. The aouthors of the textbook are Joko Priyana, Ph.D., Triyani Retno Putri Saridewi, and Yuliyanti Rahayu.

The evaluation checklist used in this paper is the modification of Cunningsworth's (1995) checklist developed by Al-sowat (2012). There are nine issues of textbook evaluating in this checklist: (1) layout and physical appearance; (2) content; (3) objectives; (4) language type; (5) skills; (6) activities and tasks; (7) structure and vocabulary; (8) culture values; and (9) teacher's needs. In each dimension, several statements provided and the textbook was graded for each statement by the rating scales range from one up to five, where $1=$ very poor, $2=$ poor, 3 = quite good, 4 = good and 5 = very good.

\section{Results \& Discussion}

\section{The Layout and Physical Appearance of the Textbook}

\begin{tabular}{lll}
\hline No. & Statements & Rating \\
\hline 1 & The textbook is durable (quality of paper and binding). & Very Good \\
2 & The size of the textbook seems convenient for students to handle. & Good \\
3 & The cover of the textbook is appealing. & Good \\
4 & The main headings and subheadings are well-organized. & Good \\
5 & The units are well organized and offer easy progression. & Good \\
6 & The textbook contains enough pictures, diagrams, tables etc. helping & Good \\
& the students understand the printed texts. & \\
7 & Illustrations, tables, figures, graphs, etc. are relevant and functional. & Good \\
8 & An adequate vocabulary list or glossary is included. & Good \\
9 & $\begin{array}{l}\text { The instructions in the textbook are written in a simple and clear } \\
\end{array}$ & Good \\
10 & language. & Good \\
11 & The material contains an adequate indices and appendices. \\
& The textbook is provided with the necessary audio-visual aids, which & Poor \\
\hline
\end{tabular}


The result of analysis suggests that the layout and physical appearance of the textbook Interlanguage: English for Senior High School students XII is suitable and appropriate to attract the students.

\section{The Content of the Textbook}

\begin{tabular}{|c|c|c|}
\hline No. & Statements & Rating \\
\hline 1 & The textbook contains an appropriate table of content. & Very Good \\
\hline 2 & The content does not conflict with students' social beliefs. & Good \\
\hline 3 & The content does not conflict with students' background. & Good \\
\hline 4 & The textbook covers most language skills. & Good \\
\hline 5 & $\begin{array}{l}\text { The subject matter is presented either topically or functionally in a } \\
\text { logical, organized manner. }\end{array}$ & Good \\
\hline 6 & There is sufficient variety in the subject and content of the textbook. & Good \\
\hline 7 & The content promotes students' autonomy. & Good \\
\hline 8 & $\begin{array}{l}\text { The content contains real-life issues that challenge the reader to think } \\
\text { critically about his/her worldview. }\end{array}$ & Good \\
\hline 9 & The topics are familiar to the learners. & Good \\
\hline 10 & The content of the material is interesting and motivating. & Good \\
\hline 11 & The content promotes students' involvement. & Good \\
\hline 12 & The textbook is appropriate for the learners' level. & Poor \\
\hline 13 & $\begin{array}{l}\text { The material encourages a positive attitude towards gender. (e.g. } \\
\text { stereotyping occupation or use of gender bias words like chairman } \\
\text { instead of chairperson). }\end{array}$ & Poor \\
\hline 14 & $\begin{array}{l}\text { The textbook encourages a positive attitude towards environmental } \\
\text { issues. }\end{array}$ & Good \\
\hline 15 & The textbook contains self-check progress report. & Poor \\
\hline
\end{tabular}

These analyses indicated that the teachers agreed that the textbook accomplished the previous items in a good manner. It was clear that the textbook contained an appropriate table of content. It also covered most language skills. In addition, the content did not conflict with students' social beliefs or their background. Moreover, the content promoted students' involvement and autonomy. Furthermore, the content contained real-life issues that challenged the reader to think critically about his/her worldview, and it was presented either topically or functionally in a logical, organized manner. Additionally, the content of the material was interesting and motivating for the students.

\section{The Objectives of the Textbook}

\begin{tabular}{|c|c|c|}
\hline No. & Statements & Rating \\
\hline 1 & The objectives in the textbook are clear and precise for the learners. & Good \\
\hline 2 & The objectives are gradual in difficulty. & Good \\
\hline 3 & The objectives are realistic. & Quite Good \\
\hline 4 & $\begin{array}{l}\text { The objectives of the materials correspond to the needs of the } \\
\text { learners. }\end{array}$ & Good \\
\hline 5 & The objectives demonstrate the various levels of Bloom's taxonomy. & Poor \\
\hline 6 & The objectives recognize individual differences. & Poor \\
\hline 7 & The objectives of the materials suit the level of the learners. & Poor \\
\hline 8 & $\begin{array}{l}\text { The objectives can be covered within the time allocated for the } \\
\text { textbook. }\end{array}$ & Poor \\
\hline
\end{tabular}

The result of analysis indicated that the objectives of the textbook did not demonstrate the various levels of bloom's taxonomy. In addition, the objectives did not recognize individual differences nor did they suit the level of the learners. Also, the objectives could not be covered within the time allocated for the textbook. 


\section{The Language Type of the Textbook}

\begin{tabular}{lll}
\hline No. & Statements & Rating \\
\hline 1 & The language used in the textbook is authentic i.e. like real-life English. & Good \\
2 & $\begin{array}{l}\text { The textbook includes materials for pronunciation work, e.g. individual sound, word } \\
\text { stress, intonation etc. }\end{array}$ & Good \\
3 & $\begin{array}{l}\text { There is an emphasis on language use. } \\
4\end{array}$ & $\begin{array}{l}\text { Learners are given examples of ways they can use their foreign language in the future } \\
\text { beyond the school experience. }\end{array}$ \\
5 & $\begin{array}{l}\text { New and critical concepts are defined in the glossary or explained when they are first } \\
\text { introduced in the text. }\end{array}$ & Poor \\
6 & The language used is at the level of the learners. & Good \\
\hline
\end{tabular}

The result of analysis indicated that the language used in the textbook was authentic i.e. like real-life English and the textbook included materials for pronunciation work, e.g. individual sound, word stress, intonation etc. There was a little emphasis on language use. Furthermore, learners were not given examples of ways they could use the foreign language in the future beyond the school experience. Besides, new and critical concepts were not defined in the glossary or explained when they were first introduced in the text. Finally, the language used was suitable at the level of the learners.

\section{The Language Skills of the Textbook}

\begin{tabular}{lll}
\hline No. & Statements & Rating \\
\hline 1 & The material provides the four language skills. & Good \\
2 & The textbook pays attention to writing activities such as controlled, guided, and free & Quite Good \\
& paragraphs. & Quite Good \\
3 & The materials for listening are accompanied by activities which help comprehension. & Poor \\
4 & The materials for spoken English (dialogues, role play, & Good \\
5 & communication activities etc. are designed to equip learners for real-life interaction. & Poor \\
6 & The reading passages are associated with pre/while/post reading activities. &
\end{tabular}

Regarding the skills processed in the textbook, the textbook did not provide enough writing activities such as controlled, guided and free paragraphs. Besides, the materials for listening were also need more activities which helped comprehension and the spoken English (dialogues, role play, communication activities etc.) were not designed to equip learners for real-life interaction. However, the reading passages were associated with pre/while/post reading activities. Finally, relevant skills such as critical thinking, problem solving etc. were poorly catered for in the textbook.

\section{The Activities and Tasks in the Textbook}

\begin{tabular}{lll}
\hline No. & Statements & Rating \\
\hline 1 & There are a variety of activities in the textbook. & Good \\
2 & The instructions in the material are sufficient. & Good \\
3 & The instructions in the material are clear. & Good \\
4 & There are instructions to explain how the exercise should be done. & Quite Good \\
5 & The number of activities is suitable. & Poor \\
6 & There are interactive activities that require students to use new vocabulary to Poor \\
& $\begin{array}{l}\text { communicate. } \\
7\end{array}$ & $\begin{array}{l}\text { The activities facilitate students' use of grammatical rules by creating situations in which } \\
\text { these rules are needed. }\end{array}$ \\
& The textbook provides communicative exercises that enable learners to carry out their & Poor \\
9 & communicative tasks in real-life situations. & Poor \\
10 & There is a balance between the activities for language and activities for skills. & Poor \\
\hline
\end{tabular}


The result of analysis indicated that there should be an improvement of this textbook regarding the activities and task provided. The poor aspects of the textbook regarding the activities and tasks included the shortcoming of the instructions in explaining how the exercises should be done. In addition, the number of activities was not suitable. Moreover, there was a lack of interactive activities that required students to use new vocabulary to communicate and use of grammatical rules by creating situations in which these rules were needed. Besides, the textbook did not provide communicative exercises that enabled learners to carry out their communicative tasks in real-life situations. Furthermore, there was no a balance between the activities for language and activities for skills.

\section{The Structures and Vocabulary in the Textbook}

\begin{tabular}{lll}
\hline No. & Statements & Rating \\
\hline 1 & $\begin{array}{l}\text { The grammatical rules are presented in a logical manner and in increasing order of } \\
\text { difficulty. }\end{array}$ & Good \\
2 & The new structure is integrated in varying contexts and situations. & Good \\
3 & The grammatical points are presented with brief and easy examples and explanations. & Quite Good \\
4 & The vocabulary load seems to be reasonable for the level of the learners. & Poor \\
5 & There is sufficient written practice of the grammatical concepts that lead to communicative & Good \\
6 & use of the language. & Poor \\
7 & The progression of vocabulary items is appropriate. & Poor \\
8 & The vocabulary is functional, thematic, authentic, and practical. & Poor \\
9 & There is sufficient oral practice of the grammatical concepts that leads to communicative & Quite Good \\
10 & use of the language. & The new vocabulary words are presented in a variety of ways (glosses, multi-glosses etc.). \\
11 & The new vocabulary words are presented at an appropriate rate so that the text is & Quite Good \\
& understandable. & \\
\hline
\end{tabular}

The grammatical rules in the textbook were presented in a logical manner and in increasing order of difficulty. Additionally, new structures were integrated in varying contexts and situations. As well, the grammatical points were presented with brief and easy examples and explanations to some extent. However, the vocabulary load was not reasonable for the level of the learners and the progression of vocabulary items was unsuitable. More to the point, the vocabulary words were not functional, thematic, authentic nor practical. In addition, the new vocabulary words were not presented in a variety of ways (e.g. glosses, multi-glosses, appositives) nor at an appropriate rate so that the text was understandable. Besides, the written practice of the grammatical concepts that led to communicative use of the language was unsatisfactory. Similarly, the new structure was not repeated in subsequent lessons for reinforcement. Finally, the oral practice of the grammatical concepts that led to communicative use of the language was not enough.

\section{The Cultural Values in the Textbook}

\begin{tabular}{lll}
\hline No. & Statements & Rating \\
\hline 1 & The content suits the learners' current knowledge and culture. & Quite Good \\
2 & $\begin{array}{l}\text { The teaching of the target culture motivates the learners to explore } \\
\text { their own culture. }\end{array}$ & Poor \\
3 & $\begin{array}{l}\text { The content serves as a window into learning about the target } \\
\text { language culture (American, British, etc.). }\end{array}$ & Poor \\
\hline
\end{tabular}

From the result of analysis in terms of cultural values, it was concluded that the content need more improvements to suit the learners' knowledge and culture. The content also did not serve as a window into learning about the target language culture. Moreover, the teaching of the target culture did not motivate the learners to explore their own culture. 


\section{The Teachers' Needs}

\begin{tabular}{lll}
\hline No. & Statements & Rating \\
\hline 1 & The use of the material is easily manageable by the teacher. & Good \\
2 & $\begin{array}{l}\text { The teacher's manual suggests an appropriate, concise method for } \\
\text { teaching each lesson. }\end{array}$ \\
3 & $\begin{array}{l}\text { The design of the materials allows the teachers to use them } \\
\text { differently according to the needs of different learners. }\end{array}$ & Good \\
4 & $\begin{array}{l}\text { The teacher's manual helps the teachers understand the objectives of } \\
\text { the textbook. }\end{array}$ & Good \\
5 & $\begin{array}{l}\text { The manual gives instructions on how to incorporate audio-visual } \\
\text { materials produced for the textbook. }\end{array}$ & Quite Good \\
6 & $\begin{array}{l}\text { The manual provides additional exercises for reinforcing various } \\
\text { language skills in the textbook. }\end{array}$ & Poor \\
7 & $\begin{array}{l}\text { Teachers are given techniques for activating students' background } \\
\text { knowledge before reading the texts. }\end{array}$ & Poor \\
8 & $\begin{array}{l}\text { The tests and assessment devices are helpful to the teacher. } \\
\text { The manual provides teachers with alternative and authentic } \\
\text { assessment techniques. }\end{array}$ & Poor \\
\hline
\end{tabular}

The result of analysis indicated that the use of the material was easily manageable by the teacher and the design of the materials allowed the teachers to use them differently according to the needs of different learners. In addition, the teacher's manual suggested an appropriate, concise method for teaching each lesson and helped the teachers understand the objectives of the textbook to a good extent.

However, the result of analysis also pointed out that the manual did not give instructions of on how to incorporate audio-visual materials produced for the textbook. In addition, it lacked additional exercises for reinforcing various language skills in the textbook. Besides, alternative and authentic assessment techniques were not offered and the tests and assessment devices were not helpful to the teacher. Additionally, teachers were not given techniques for activating students' background knowledge before reading the texts.

\section{Conclusion}

The results obtained from this analysis proved that the textbooks had some problems. According to the evaluation checklist, it could be concluded that the layout and physical appearance, the content and the objectives were appropriate as a textbook for the senior high school students. Furthermore, the instructions in the material were sufficient and clear. It also provided the new structure that was integrated in varying contexts and situations. Additionally, the teacher's manual in the textbook helped the teachers understand the objectives of the textbook.

However, These results implied that there was weakness in language type, skills, structures and vocabulary, teacher's needs, activities and tasks and culture values for the senior high school students.

\section{References}

Al-sowat, Hamad. (2012). An Evaluation of English Language Textbook "Say It In English" For First Year Intermediate Grade in Saudi Arabia. Journal of Studies in Curriculum and Supervision, 3(2). Retrieved from http://uqu.edu.sa/files2/tiny_mce/plugins/filemanager/files/4280212/GES3-2-5.pdf

Awasthi, J. R. (2006). Textbook and Its Evaluation. (Online). Vol.11 No. 1-2. (www.nelta.org.np) 
Cunningsworth, A. (1995). Choosing Your Coursebook. Oxford: The Bath Press.

Park, E. (2004). A Study on English Textbook Used in a Technical High School: Issues in EFL. (online), Vol.3 (http://TEFLIN.journal.ac.id) 